\title{
Multi-level finance and the Euro crisis - causes and effects
}

\section{EHTISHAM AHMAD, MASSIMO BORDIGNON} and GIORGIO BROSIO (Eds.)

Edward Elgar Publishing, Cheltenham, UK, Northampton, MA, USA, 2016, pp. 367

Book review by PREDRAG BEJAKOVIĆ*

https://doi.org.10.3326/pse.41.1.11

\footnotetext{
* Received: January 9, 2017

Accepted: January 11, 2017

Predrag BEJAKOVIĆ, Ph.D.

Institute of Public Finance, Smičiklasova 21, 10000 Zagreb, Croatia

e-mail: predrag@ijf.hr

ORCID iD: 0000-0002-4164-8220
} 
The relationship between central and local government is always complicated, particularly in a time of economic crisis, insufficient public revenues and increased demands of an electorate that wants to keep the existing level of social services with lower costs. The new book Multi-level Finance and the Euro Crisis-Causes and Effects is a significant collection of contributions that effectively shed light on the mentioned relations in a fairly large group of countries. This book raises a number of crucial fiscal and political economy questions, such as, what was the role of local and regional governments in the crisis? How did conflicts between different levels of government contribute to the worsening of fiscal indicators and deepening of the crisis? Is there any golden rule to solve the fiscal problems and the situation from the supranational to the local? The publication contains these and many other important issues that have been mostly neglected, regardless of their relevance.

In the introduction chapter, the editors Ahmad, Bordignon and Brosio remind us that the euro area has been caught in a vicious circle of deflation, weak demand, insufficient investment and increased unemployment with a high share of people that have to wait a long period for a job. All this leads to increasing social conflict and centrifugal trends (for example, a tendency to accept less EU integration). Obviously, the crisis shows that the promises of development, harmony and prosperity that were the basis of the EU are almost unattainable goals. This is particularly true when one considers that due to high budget deficits and increased public debts, in many countries there is a need for further reduction and limitation of basic public services and employment in public and state sectors. It seems that the northern European countries are behaving in a more serious and responsible manner than other EU members, and have managed their public finance better during the crisis. This does not mean that they do not also have serious problems with fiscal and organisational adjustments in the relations among various levels of government, primarily a clear division of authority and responsibility, as well as with insufficient accountability in some cases. In many countries, sub-national governments very often participate in the game-play, with the desire to avoid regulations on expenditures, hiring, or deficits. This is usually done by putting liabilities in activities or means that are complicated to control, or by using publicly owned private enterprises to perform on their behalf. The central governments usually try to improve accounting rules and information requirements and pressure the local governments to accept more incorporating budget rules.

Teresa Ter-Minassian analyses the importance of stimulating stabilizing and sustainable sub-national fiscal policies in the euro area (EA). She points out that the public finances of the EA member countries have been significantly impacted by the two crises. First, through the functioning of the automatic stabilizers, discretionary stimulus packages in 2008-2009, and in some countries the payment of contingent liabilities, particularly from rescue operations for domestic banks. These triggered an increase in the average gross public debt, causing the need for significant future fiscal adjustment efforts. As there are differences between EA 
member countries (four are federations, while fourteen are unitary states) there is a wide array of intergovernmental fiscal arrangements, variations in the degree of revenue and decentralization of expenditure, the statutory and de facto autonomy of their lower level governments and systems of borrowing controls. The initial reaction of most EA central governments (CGs) to the global financial crisis in 2008 was to accommodate the effect of the automatic fiscal stabilizers on the revenue side of the budget and cyclically sensitive expenditures, and to adopt and implement stimulus measures. Their goal was to stimulate plummeting domestic demand, mostly through various forms of tax cuts, increases in transfers to families and firms, and reduction in public investments. In many countries, national governments transferred through their sub-national governments (SNGs) a substantial share of the increased spending to compensate them for reduced own or shared revenues. Thus, the share of intergovernmental transfers in total sub-national revenues and the share of sub-national spending in GDP increased. Many central governments try to ensure fiscal responsibility and longer-term debt sustainability of sub-national governments and for these goals use various types of borrowing controls. Some focus on minimizing pro-cyclicality measures and try to protect the quantity and basic characteristics of essential public services delivered at sub-national level. In the search for responsibility, discipline and debt sustainability, standing fiscal rules have been most often used. Although usually focused on debt sustainability, they keep some space for borrowing to finance public investments. The most common combination has been a golden rule - an obligation that requires at least balanced current budgets of sub-national governments. In the implementation of various measures, the main challenges are to define adequate criteria and mechanisms for the vertical and horizontal distributions of general government budget targets and debt ceilings; to minimize risks of sub-national pro-cyclicality; and to preserve appropriate space room for public investments. For the successful achievement of defined goals - primarily promoting sub-national fiscal discipline - it is crucial to provide a robust and stable legal framework and to define a responsible body to monitor sub-national compliance with the rules and/or agreed targets. Probable weaknesses in monitoring and enforcement mechanisms can undermine the effectiveness of both rules and negotiated arrangements.

Although coordination and control mechanisms mostly differ in various countries, there is no possibility that they will be effective without full and timely information on the nature and timing of the financial obligations. Thus, Ehtisham Ahmad writes on the political economy of information generation and financial management for SNGs. He firmly believes that effective management of liabilities is critical to ensuring a better buy-in from the private sector and a more credible environment for greater stability for contracts. An appropriate institutional framework is a precondition for successful management of budget revenues, expenditure and tax assignments. Such a framework and adequate policy design are required to provide proper incentives to sub-national governments, by, for instance, expanding own-source taxation at lower levels. Furthermore, it is important to adopt more flexible and effective budget management elements. These activities must 
be supplemented by uniform budget standards to reduce or at least to limit the problems with asymmetric information and game-play between enterprises and the public sector as well as between the centre and lower levels of government. Political gaming operates even in Germany, probably the most responsible country in Europe, which produces a bad impression and a negative impact on the weaker countries, reducing incentives for responsible behaviour.

The reader can ask why Germans are so loath to be in debt. The answer is provided by Georg Milbradt who explains the development of budget rules and national and sub-national debt in recent German history. To understand the reasons behind the concept of German behaviour regarding debt (which was in a modified form introduced at the European level), one has to look at German historical experiences. During the $20^{\text {th }}$ century, the German population lost its monetary resources twice. The first time in 1923, in the hyperinflation crisis that resulted in an unbelievable exchange rate of one trillion old Mark to one RM (Reichsmark). The second time, after the Second World War, when the currency reform of 1948 resulted in an exchange rate of $100 \mathrm{RM}$ to 6.5 DM (Deutsche Mark) in the West, and significantly greater losses in other German territories. After the unification, a West German bailout helped to avoid a third sharp devaluation in the former East Germany. The reason behind these drastic devaluations was that German governments financed their expenditures primarily via debt, and used the printing press, either directly or indirectly. The hyperinflation caused great social tensions and is often considered a key element in the rise to power of the fascist government. Thus, aversion to debt financing and inflationary policy is deeply rooted in the German collective memory.

Financial problems in the biggest countries in Europe - Germany and France are presented in the second part of the book. In Germany, according to Paul Bernd Spahn, apart from their dominant role in public fixed capital formation, local governments are also strongly committed to spending on social assistance. These outlays have tended to grow primarily due to unfunded mandates heaped upon local governments by federal legislation, for example, the newly introduced right of a kindergarten place for each child. Not surprisingly, over the longer period, local taxes and state transfers could not keep pace with the local social expenditures, which exposes the structural weakness of the local government sector. This was one of the most important reasons why Germany was the first country on which a formal EU mechanism sanctioning excessive deficit and debt was imposed, in 2002. Pierre Garello describes how France was exposed to the same procedure in 2003. One of the causes of fiscal problems in France is the chaotic and sometimes confusing decentralisation process with complex division of national territories, départments and regions. This is further aggravated by an increasing lack of transparency in local governance since the representatives at the council of the inter-municipal administration are not directly elected but are appointed by the council of the municipality. Such a situation made it very hard for taxpayers to understand the responsibility, authority and accountability of a 
particular level of government, who is managing what and with whose money costs have been covered. Furthermore, some very big part of public expenditures like the social security budget is almost beyond the control of the parliament. The analysis provided clearly shows the need to clarify the responsibilities devoted to each level of government and to allocate financial resources in a way that makes each level accountable.

The situation regarding central and sub-national governments is particularly worrisome in the countries of Southern Europe, so the third part of the book examines the situation in Greece, Portugal, Spain and Italy. Each of the mentioned states has own specificities. Chortareas and Logothetis explain the crisis in Greece by a number of accumulated macroeconomics and institutional weaknesses. Macroeconomic problems are primarily linked to structural deficiencies and a lack of competitiveness, while institutional troubles are related to a lack of clarity about local and municipal functions. By contracting arrangements for local services, wages are paid by the central government, while liabilities are parked in public enterprises and off-budget entities. In the reform of the territorial organisation of local government, the number of municipalities decreased, but their responsibilities were broadened. The reduction aimed at creating economies of scale to increase local government efficiency, but this has not been fully achieved probably due to widespread rent-seeking and the extensive clientelistic and electioneering practice that characterised local politics.

Mário Fortuna explains the situation in Portugal, where sub-national government behaviour has impacted the financial crisis directly and through local municipal enterprises. Portugal is characterised by inadequately designed accounting rules, serious structural problems regarding the sustainability of local finance and poorly managed equalization transfers. This leads to the frequent application of soft budget constraint at the sub-national level. In order to circumvent stricter fiscal rules, municipalities and regions broadly use public-private partnerships and/or hide liabilities in publicly owned enterprises, and resort to other off-budget practices. In addition, the transfers are not made a function of needs, but of potential revenues. Thus, on average the municipalities with the highest GDP per capita and own revenues per capita receive more transfers per capita, which means that the existing system does not contribute to equalization. Due to the changes in intergovernmental relationships caused by the crisis, the reform of the budget framework law, reduction in transfers and wage cuts at the local level, more comprehensive budget rules to eliminate off-budget practices were adopted. In addition, the information on fiscal flows and local taxes was improved and is now given in more detail. There is also an intention to reduce the number of municipalities. Particular attention is paid to establishing a stable rule of transfers, which is quite opposite to the recent practice of transfers based on political negotiation, leading to a very uncertain and subjective process. All reforms tend to make sub-national government more accountable, and one can hope that with more fiscal autonomy the citizens will be better aware of the costs of public spending. 
According to Lago-Peñas and Solé-Ollé, the current crisis in Spanish public finances has both external and domestic origins. The real estate bubble at the beginning of the 2000s was caused mostly by the flows of international capital after the accession of Spain to the Eurozone. The domestic causes consist mostly of the inadequate decentralization process, the inappropriate tax system, an insufficient fiscal discipline and weak institutions. Additionally, there is an inefficient model of equalization transfers, mostly related to ad hoc criteria and political bargaining in defining the amount of equalization grants received by regions. With the decentralization of the 1990s, significant responsibilities in the management of important social policies, such as health and education were given to the lower level of government, which had limited tax autonomy. After receiving financial windfalls from the real estate boom before the crisis, sub-national governments deemed such revenues to be permanent, which induced overspending. The resulting increase in corruption among local and regional politicians ruined the quality of political accountability. With the bursting of the real estate bubble, all levels of government experienced a serious financial crisis, with rapidly increasing deficits and debt levels. Realised reforms were insufficient and were halted due to the empowerment of populist parties.

Unlike in Spain, according to Ambrosanio, Balduzzi and Bordignon, the dire situation of public finances in Italy did not allow the activation of a counter-cyclical policy when the economic crisis hit the country in 2008. This led to massive fall of output and employment, which had only partially been recovered by 2010 . The 2011 euro crisis was followed by massive capital flight and called into question the sustainability of the huge national public debt. This forced the country to begin with a serious and demanding fiscal adjustment programme that pushed the economy into an even more serious recession. Taxes were sharply increased and capital expenditures more than halved. Current expenditures were frozen in nominal terms, with an impact more or less equally distributed between the centre and sub-national governments. Local and regional governments were forced to raise money, through enforced savings, to finance the general government budget. The crisis effectively changed the real balance of power between different levels of government, leading to recentralization. Provinces were abolished, while regions' functions were drastically reduced. Time will show how realised and further reform for more efficient and responsible system of government may eventually lead to a return to sustainable economic growth.

Brosio, Piperno and Suarez Pandiello examine the ways in which Barcelona and Turin managed the problems of the Olympics, a highly costly and financial risky event for the soundness of municipal finances. The impact of the nomination of a city as the organizer and the needed decisions and investments, range from the most physical (construction projects) to the most intangible (local self-esteem or international impact, one of the most valued effects). Regardless of significant transfers from central states and revenues from sponsors, host cities are held responsible for the success of the event, which can imply significant unexpected and 
unplanned outlays. Host cities can be tempted by the exceptionality of the event to implement projects associated with urban transport and thus to cause increased expenditures. Turin with its underground network, finished two years after the Games, is an excellent example for such renewal projects called the Olympic legacy. While the population of Barcelona was willing to continue to pay higher taxes for the benefit of better public services and help to regenerate the city, which in turn attracts further investments and growth, this was not the case in Turin. There the investments did not have an equal regenerative impact, and the city was unable to regain its role as the regional industrial hub. The Summer Games because of their large size, might generate positive effects in the mid-term as touristic attractive location, and in the long run can improve the openness of the market and internationally visibility, which can attract new and sustainable economic activities. While Barcelona was a success story, this was not the case with Turin, which should be a lesson for the future organizers of such huge events.

The problems of relations between the central state and subnational government in accession countries are analysed by Marjan Nikolov using the case of Macedonia. The higher autonomy offered to local government via free access regarding the property tax allowed them to cope better with the effects of the economic crisis, in spite of reduced transfers from the centre. The process of decentralisation was based on the gradual devolution of responsibilities given the increased capacity of local governments to manage tasks, and on the provision of equitable and adequate transfers from the central government. However, there have been constant problems with fissures in intergovernmental fiscal relations as well with the lack of clarity regarding the authority and responsibility of various governmental levels. Furthermore, although relatively well protected from the global economic crisis, there were no efforts by the central government to compensate local government for the revenue shortfall resulting from the impact of the economic crisis. Instead, VAT transfers were lowered, despite legal requirements, which has caused serious problems for local governments. In the existing decentralisation process, all local governments have the same responsibilities regardless of their size and tax capacity, while the benefits of local autonomy go hand in hand with greater levels of inequality. In that way, the central government should consider developing a more explicit grant system for horizontal equalization.

The book finishes with a section dedicated to some general lessons containing two contributions. The first by Alex Mourmouras and Peter Rangazas examines clientelistic politics and multi-level finance and the consequences of this relation to regional inequality and economic growth. The persistence of backward regions in generally successful growing middle and high-income countries has been a longstanding policy issue. Since regional development and income diverged, concern over increased regional differences resulted over the course of time in bigger regional transfers. In the analysis of the interactions between central and local governments regarding the distribution of grants with particular attention to the poorest regions, there is a need to use a political economy framework. In it, the 
relations between levels of governments are strongly determined by mutually beneficial political trades. Politicians at various governmental levels through clientelistic politics collude, exchanging transfers for electoral support. Such a political setting is often characterized by corruption, particularly at the local level and in the underdeveloped regions, which causes significant suboptimal solutions. There are no simple solutions for such behaviour, but it looks as if co-finance arrangements for transfers can help reduce the leakages. Furthermore, other fiscal rules - like stricter implementations of financial constraints and debt limitations - can be useful to fortify budgetary constraint.

Over the last decades, fiscal decentralisation has been implemented in many European countries in the hope of enhancing governance and budgetary efficiency. Efficiency gains are based on improved information, competition and accountability, but there are also possible disadvantages of decentralisation. Using the case studies explained in the book, Leo Fulvio Minervini and Annalisa Vinella deal with the political economy of incentives and non-respecting budget constraints. Soft budget constraints may not fully internalize the costs of local spending if they are financed through a common pool of transfers from the central government. Furthermore, if local government is aware that central government will be at its disposal in the event of it defaulting, obviously, moral hazard can appear and/or local government will be inclined to overspending and may restrain its tax effort. The authors deem that in some rare cases, there can be a welfare gain in the central government guaranteeing important and critical investments, even if this can cause a softening of the existing budget constraint at the sub-national level. In the case of asymmetric or incomplete information, the central government can take advantage of the uncertainty and avoid rescuing a lower level of government, which can be a motivation for implementation of effective fiscal measures. The most important measure against soft budget constraints is a good guide for policy making.

The authors clearly show the complexity of multi-level finance and inform the readers on many crucial fiscal and political economy phenomena. Their contributions are even more important because these intricate issues have been mostly neglected in spite of their relevance. In the period of increased demands for efficient spending of public money under current fiscal decentralisation, there is an obvious need for establishing sound financial management for the delivery of local services. For such a task, it is important to establish transparent rules and criteria as well as to improve monitoring capacities. There are probably no easy solutions for these complex problems, but this book is without doubt a praiseworthy contribution to the improvement of the dire situation with multi-level finance in Europe. 